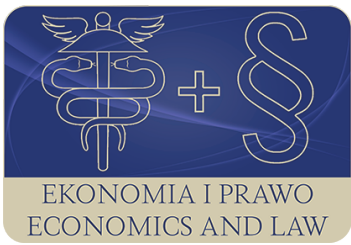

EKONOMIA I PRAWO. ECONOMICS AND LAW

Volume 17, Issue 4, December 2018

p-ISSN 1898-2255, e-ISSN 2392-1625

www.economicsandlaw.pl

ORIGINAL ARTICLE

received 02.01.2018; revised 10.05.2018; accepted 31.12.2018

Citation: Zatwarnicka-Madura, B. (2018). Gender roles and online marketing communications in real estate markets. Ekonomia i Prawo. Ecomomics and Law, 17(4): 459-469.

doi:10.12775/EiP.2018.033.

\title{
Gender roles and online marketing communications in real estate markets
}

\author{
BETA ZATWARNICKA-MADURA \\ Rzeszow University of Technology, Faculty of Management, Department of Marketing, \\ al. Powstańców Warszawy 12, 35-959 Rzeszów, Poland \\ $\square$ bezat@prz.edu.pl
}

\begin{abstract}
Motivation: The real estate market has attracted a lot of public interest due to its significant economic role. Changes are, however, going to abound in the nearest future as a result of difficulties in accessing housing loans and amendments to the building construction laws, amongst others. This will call for even greater involvements of tenderers in the marketing communication process. Gender-related differences in the purchasing decision making process is growing in significance and should be reflected in marketing communications.
\end{abstract}

Aim: The aim of the article is to identify contemporary activities undertaken in marketing communications in the real estate market. Specifically, greater attention is paid to the gender roles of both - suppliers and customers. Another objective is to analyse the use of one of the most significant tools of marketing communications namely, the internet in the real estate market. The study involved the use of literature analysis and criticism, web content analysis provided by vendors of real estate as well as telephone inter-

views with representatives of both property developers and real estate agents.

Results: Online marketing are the most important means of communication in real estate markets. The websites of real estate agents and property developers vary a lot. Real estate vendors, very often, make use of social media in their marketing communications. One of the most common trend is to make use of images instead of texts in marketing communications, thus creating new possibilities of communication. Very few property developers and real estate agents exploit the knowledge of gender-related differences in the reception of marketing messages. Only few communication activities take cognisance of gender roles. The need to focus marketing communications in real estate on young customers has necessitated the engagement of new media sources in communication activities. This 
desire for a better adaptation of offers to consumer needs, calls for the use of new technologies such as mobile applications that are augmented by reality or virtual reality.

Keywords: marketing communications; real estate market; gender roles JEL: M21; M31

\section{Introduction}

The real estate market arouses considerable social interest in many countries due to its significant economic role. Intense competition and macro-economic changes call for even greater involvement of vendors in marketing communications processes. Marketing communication, as a specific corporate dialogue with other actors in its market environment, stimulates demand and shapes consumers' needs. Both information exchange and the relationship between a company and its customers is of value for both parties (Fill, 2006, p. 8). The composition of the set of marketing communication tools is not clearly defined, but it usually includes advertising, personal communication (sales, personal sales), sales promotion, and public relations (Meffert, 1986).

Real estate is a very complex product. Since it is rarely acquired and needs the engagement of huge financial resources, the immense significance of interpersonal communication between vendors and buyers cannot be overlooked. Gender differences are becoming increasingly important in the purchasing decision making process (Barletta, 2006, pp. 15-33; Feingold, 1994, pp. 429-456; Fischer \& Arnold, 1994, pp. 163-182). This should be reflected in marketing communications, especially since women have a strong influence on property purchases.

The Internet has been of significant importance for marketing communications in the real estate branch. According to Ren (2015, pp. 220-223), the Internet can change the way information is acquired, including the aggregation and integration of effective information. He has demonstrated in his article, by analyzing the impacts of the Internet on the real estate industry, that the Internet has changed the consumption trend, which is a key link between marketing and consumer demand. A more comprehensive research on the impact of information and communication technologies in the real estate industry was conducted by Kummerow \& Chan (2005, pp. 173-190). It is argued that consumers were the main beneficiaries of technological change.

The research objectives discussed in the foregoing paper include the following:

- identifying relevant, contemporary activities in the area of marketing communications in the real estate market;

- determining the gender of real estate agents (seller, agent, broker, agent, sales representative) and the recipient of their offers;

- determining whether the gender of the recipient of real estate marketing message is taken into account by their broadcasters (vendors);

- analyzing the use of the Internet as one of the most important marketing communication tools in real estate market. 


\section{Literature review}

\subsection{The role of the vendor's gender in the real estate market}

More than $60 \%$ of people employed in real estate services in Poland are women (GUS, 2016). An interesting research on gender composition of the real estate market was conducted in Sweden, where about 40\% of employees are women (Staffansson Pauli, 2014, p. 5). It follows that men are more often in higher and technical positions, while women remain in supporting positions and not as often in positions such as a real estate manager (Staffansson Pauli, 2014, p. VI). Similar results were obtained from studies in Australia (Dimovski et al, 2016, pp. 18-28). The study revealed that the Financial sub-sector of the entire Industry, Real Estate Management and Development (REMD) companies have the lowest proportion of female directors on theirs boards - eight women on each of the 35 analyzed company boards compared to 159 men on each of them in 2011.

In Poland, women in the real estate market are doing very well, representing both the sellers and buyers. Women as sellers prepare more scrupulous than men in for real estate transactions than men. Scrupulousness is already evident at the stage of sales announcement drafting. Women are well prepared to show detailed elements of an apartment, which for men is often reduced to the location, size, number of rooms and price per square meter space. For women, however, aspects such as the layout of the apartment, its geographical positioning, the view from the window or illumination are important. Women who sell apartments are also better prepared than men to talk with potential buyers and are more effective negotiators, as reflected in the statistics (Turek, 2013). Buyers were able, in the case of re-sale flats sold by women, to negotiate an average of $4.3 \%$ discount. Men agreed to make some more generous concessions by decreasing the price by $5 \%$ on average. Women are also quicker at finding buyers for their apartments.

The gender of an agent in the real estate market is important, especially in price negotiations. The evidence suggests an interesting alternative to agent performance namely, that buyers and sellers with different reservation price and time on market expectations, such as those selling foreclosure homes, tend to select agents along gender lines (Seagraves \& Gallimore, 2012, pp. 600-631). In other interesting, but not gender-related studies conducted in Taiwan (ShuMan et al., 2012, pp. 321-348) the behavior of the real estate brokerage industry from the perspective of homebuyers was analyzed. Empirical results regarding sales ethics show that whenever homebuyers believe that advertising sales agents behave ethically, their negative impressions regarding the advertising sales agents decline. In the past, homebuyers were forced to deal with exaggerations, lies and distortions by agents. The results of the current study 
show that focusing on ethics is one of the best approved methods for improving customer satisfaction and minimizing customer complaints.

\subsection{A buyer's gender role in real estate market}

Although women earn less than men in Poland they, however, move out of their family homes much faster. According to Eurostat (2013) data, women move away from their parents 12 months earlier than men. Polish women in the pre35 age group leave the family homes on average at the age of 27.3. For men, the average age is 28.3, which corresponds with the average level for the "new EU' countries. Women are, for this reason, increasingly looking for real estates.

Gender significantly differentiates approaches to limiting risks associated with acquiring real estate. Women pay more attention to the limitation of this type of risk than men do. According to a survey of over 1,000 Home Broker clients, up to $58 \%$ of women consider it as important to avoid the risk of non-completion of building constructions compared to 51\% for men (Turek, 2012). As a result, men are more likely to use the primary market. The desire to own a new home is at least moderately important for $90 \%$ of men and $80 \%$ of women. Women in Poland pay more attention to the interior finishing in accordance with their taste - this is important for $87 \%$ of women, but only for $78 \%$ of men. The studies conducted in Slovenia and Japan on the expectations of potential acquirers of residential real estate rights show that the participants are more expressive than men (see Grum \& Salaj (2010, pp. 501-516)).

Gender, a key variable in marketing segmentation and research often indicates different responses from males and females, regarding their use of the Internet for online shopping, communication and relationship management (Chan et. al., 2015, pp. 182-206). Significant differences in the perception of Internet messages by women and men are also analyzed and described by Perju-Mitran \& Budacia (2015, pp. 567-573), who advocate that different strategies should be applied for both genders:

- men - strategies for highlighting informative character and usefulness, with cognitive and symbolic level interventions through an objective placement;

- women - strategies for trust building and personal relevance. Women seek additional information if brand positioning seems trustworthy and relevant to their interests, so affective and conative level interventions will be better appreciated, focusing on the emotional and symbolic positioning to highlight imaginary brand functions and allow the user to assert themselves socially by association with the respective brand.

\section{Methods}

The critical literature review, telephone interview and web content analysis methods were applied to accomplish the three research objectives. 
Telephone interviews were conducted with employees of 12 real estate agents and developers located in Rzeszow, a provincial capital city in south-eastern Poland, with about 200,000 inhabitants. The interview focused on the most commonly used office communication tools and their differences in approaches to women and men. The interviews were conducted from 6-10 March 2017.

The web content analysis method is an objective, systematic and quantitative description of the apparent content of the messages. The research difficulties included:

- Do the websites of real estate agencies contain relevant information?

- Identifying existing ways of presenting real estate offers on the Internet.

30 web pages were selected for the content analysis. These were the first results in the most popular Google search engine (97\% of users) listed under the entry 'Rzeszów real estates'. The content analysis was carried out 13-17 March, 2017.

The following difficult issues, regarding the websites offering real estate, were identified:

1. company presentation:

- the company as an organization: mission, goals, successes;

- the company as a team: presentation of the board and employees;

- the company as a business partner: standards and principles of cooperation, benefits to the customer;

- the company as an advisor: information about services other than sales (credit counseling, etc.);

2. information that make a company reliable:

- awards, successes, affiliation, social and charitable activities, etc.;

- recommendations of satisfied customers;

- recommendations of famous people/companies;

- partners: consulting companies, organizations and associations, media, etc.;

- a company in the media (press articles, radio speech and TV);

3. seller/buyer department (basic information for each of these groups - why should they entrust the transaction to this company?);

4. current offer base;

5. search engine offer;

6. registration forms (real estate to buy and sell, customer and journalists applications);

7. social media;

8. added values of the service:

- tutorial texts;

- market data (statistics, summaries, etc.);

- credit calculator;

- useful links;

- search information in the real estate market, etc.;

9. the use of audio-visual technology;

10. contact. 
With regards to ways of presenting a real estate's offer on these websites, the following factors were identified:

- property information - scope, content, form;

- graphical presentation - photos, maps, signs;

- data about the area;

- contact with an advisor;

- charges calculator.

\section{Results}

\subsection{Gender-related marketing communication in the real estate market}

An analysis of secondary sources and interviews conducted with real estate agents' employees shows that the Internet is of great significance in the communications of real estate agents. Internet advertising as a type of promotion aimed at informing about and inducing the purchase of certain real estates or services is, most often, conducted on their own web sites and in the form of web-based advertisements (in advertising services). Advertising activities involve the application of various channels such as newspapers, radio, television, magazines, posters, advertisements, and inscriptions. The most popular types of channels in Rzeszów's local market include advertising banners located on the property sold and classified ads. Press releases and leaflets are, however, less popular.

Public relations is an important promotional tool for a company's activities in areas of communication and mutual relations, whose main essence consists in taking care of the good image of a real estate agent. Public relations play a special role in the Internet as they are based entirely on the communication process. Internet based public relations activities are primarily used in all major Internet tools such as websites, email, and discussion forums.

The so-called personal promotion (personal sales), which involves interpersonal contact of a property agent with a prospective client also plays important roles in marketing communication. The psychological mechanisms of personal promotion make the transfer of some of the vendor's sympathy and acceptance to a product possible (see: Zatwarnicka-Madura (2004, pp. 28-140)) . The responding real estate agents highlighted the importance of this form of promotion and pointed out the different ways of communicating with women and men.

Women, in the opinion of real estate experts and practitioners, have a very strong influence on decisions regarding the purchase of real estate. This is partly due to the growing role of women in household shopping planning and to the fact that, when choosing places of residence, the family decides to organize those spheres of life that are traditionally managed by women. As many as $54 \%$ of site developers are women. However, developers, who want a woman to get interested in buying a flat, have to completely differentiate the marketing process 
. Women are more likely to act in groups and be family oriented than men, and are more willing to take pro-social actions. They also pay more attention to details and can handle several tasks simultaneously. Since women are multi-tasking, they expect the same products and services. Moreover, when preparing advertisements for women, it is important to remember that they take the world more by their senses namely sight, hearing, touch and taste than men do. Specialists point out that it is worthwhile exploiting the potential of women's lives by planning online campaigns as women (72\%) now use the network extensively - daily or almost daily. The features of the Internet that make it a popular medium are the ease of communication, interesting and comprehensive content, convenient shopping and social groups in which women are eager to participate. Women are also very profitable customers and although they spend more time finding the perfect product, they remain more loyal.

When choosing real estate women are guided by feelings and they pay more attention to the aesthetic appeal of the apartment and its location. For them the arrangement of children's room, access to a kindergarten or school, kitchen area and its functionality, a view from the window and the cost of living are important. In Poland, there is the belief that women are more emotionally driven than men. However, in the process of buying a home, which in itself is an emotional act, women do not only rely on emotions, they are also increasingly exploring knowledge about the techniques and materials being used. It follows from the observation of developers that women are, in a sense, the driving force behind the dream of building a home. It can be concluded from the telephone interviews with real estate agents and developers that two thirds of the apartments are purchased by women.

Men, buying real estate pay attention to the infrastructure, first the service points, the garage or parking space and technical parameters such as the possibility of rearranging the purchased apartment, the TV access, and the acoustics of the apartment. It must be emphasized, however, that any advertising aimed at men should not be created on the basis of gender-based discrimination. Men of all ages pay attention to completely different elements. However, one can clearly distinguish several features of an advertising message that is more likely to attract a man's attention. First of all the message should be short, condensed, product information and a service should be aligned with the qualities or values that men can relate to, to measure their satisfaction with the product. It is also worth to use a lot of new information because this type of argument is of particular interest to men. It should also use more graphics and less content since this kind of ad would help to draw attention and reach the male consumer.

The gender of the receiver of marketing communications in the real estate market is rarely taken into account by their broadcasters in advertisements. One of the most interesting examples of this kind is the idea of the Belgian branch of the International Century 21 real estate agent that put together a campaign which has been attractive for various reasons for both genders with the help of a publicity agency. A mail shot, whose slogan was 'When life changes your 
plans' was prepared. The mails were sent to young or future parents. Customers were presented plans of flats or houses whose layout resembled the silhouettes of people: women, men, children. These plans were printed on Al-size paper normally used to print real architectural plans.

For women, this is an eye-catching marketing communication because it portrays people, a story about them, which gives them positive emotions and makes them perceive Century 21 as the company that understands people, their needs, their often confused personal affairs. Men, who are more interested in technical issues, will see plans of flats and homes that have specific functions, specific equipment, a place tailored for the current and future needs of the family. A man seeing the architectural plan will know he is dealing with an advertising agency who is well-oriented. This campaign is a great example of marketing communication that will be well received by both women and men, without unnecessary words and talk. Century 21 has emerged as a worthy partner to talk with regarding the purchase of one of the most expensive products for both genders, irrespective of whether they are talking about buying a property individually or together.

\subsection{Analyzing the use of the Internet in real estate market}

Real estate agents use the Internet primarily through their own websites, advertising services and social media. One of such key tools is the Internet advertising service. Agents have a huge number of sites to choose from, so the decision of who to patronize is not easy. Research on this issue was undertaken by PBS Agency, that carried out the CAWI study in March and April 2015. 268 Real Estate Agents employees from all over Poland participated in the survey. Most of them (95\%) used the Otodom service the previous year. The next highly rated services were Gratka and OLX.pl with $81 \%$ and $73 \%$ respondents respectively.

The results of the survey indicate that the most important argument for agents to use a particular site is the number of property-related requests from potential customers that use the site. Visits Statistical data relating to visits and portal popularity are other elements that mediators pay particular attention to. They were successively followed - by the matching of listings to the needs of the office, costs of posting notices, the ease of use of the user account, customer support and access to industry-related analyses .

The core of any PR activities should be the website of the real estate agency or a developer. It should fulfill a number of requirements, including: attracting as many visitors as possible to the site, maintaining interest in the site, and establishing a two-way communication with Internet users.

The content analysis in the current study concerned 30 websites (of real estate agents and developers), linked with the searched phrase 'real estate Rzeszów' after Internet advertising services from real estate had been eliminated.

Table 1 presents the content of the analyzed web pages in both quantitative and percentage terms. 
The analysis shows that the presentation of a real estate office or a developer is usually a brief description of the company as an organization, a business partner and/ or a consultant. Very rarely do such companies present their team (6\%). Most real estate agents (50\%) cite their business partners as respectable sources of information concerning them. Recommendations from satisfied customers and information about awards, successes, etc are contained on every fifth page of the real estate and developer's website. The vast majority of companies have their current base of offers on their websites. Due to the fact that a part of the analyzed companies were real estate offices while the other were developer's offices only half of the analyzed sites had sections for sellers and buyers and registration forms for purchases and sales. References to social media were only identified on 8 websites. The most often occurring added values of the sites are its pop-up guidance texts (53\%), useful links (50\%) and a loan calculator (47\%). It is somewhat surprising that audiovisual technology is applied only to one-fifth of each page.

All analyzed web pages with respected real estate presentations, contained information about the property, graphic presentation, locational data as well as contact details to the advisor. Not all analyzed sites (73\%) had a fee calculator included.

\section{Conclusions}

The research has confirmed that the Internet exercised the greatest influence in marketing communications in the real estate market. As earlier indicated in the paper, gender does play important roles in the real estate market, both in aspects of the vendor and the buyer. Persons responsible for communication activities ought to pay specific attention to gender issues. Since women as buyers analyze offers in more details than men, it worth preparing two versions of the same offer, namely a general and a detailed one. In creating advertisements for women, it should be noted that they, unlike men percieve the world through their senses of sight, hearing, touch and taste. The real estate market communication activities directed at women should also care for the aesthetic aspects and pro-social impacts of the offer. The real estate offer for men ought to, on the other hand, emphasize the infrastructure and technical details.

The fact that awareness of gender differences in marketing communications is still low was confirmed in interviews conducted with employees. Some of them stressed the existence of differences in personal communication, but in no other form of communication did they notice such a need. The content analysis of websites has shown that companies located in medium-sized provincial cities have websites that could be much more technologically advanced, especially in how to present real estate using audiovisual technology. However, the results cannot be generalized, as primary testing was performed on a small sample. An additional limitation was the conduct of the research among companies located only in one city. It would certainly be worthwhile to conduct 
further studies with a larger number of responding companies and on a wider territorial scale.

\section{References}

Barletta, M. (2006). Marketing to women: how to understand, reach, and increase your share of the world's largest market segment. Chicago: Deaborn Publishing Trade.

Chan, T.K.H., Cheung, C.M.K., Shi, N., \& Lee, M.K.O. (2015). Gender differences in satisfaction with Facebook users. Industrial Management and Data Systems, 115(1). doi:10.1108/IMDS-08-2014-0234.

Dimovski, B., Lombardi, L., Ratcliffe, C., \& Cooper, B.J. (2016). Australian real estate management and development companies and women directors. Property Management, 34(1). doi:10.1108/PM-12-2014-0052.

Eurostat. (2013). European social statistics. Retrieved 12.12.2016 from http:// ec.europa.eu/eurostat.

Feingold, A. (1994). Gender differences in personality: a meta-analysis. Psychological Bulletin, 116(3). doi:10.1037/0033-2909.116.3.429.

Fill, C. (2006). Simply marketing communications: engagement and practice. Edinburgh: Financial Times Prentice Hall.

Fischer, E., \& Arnold, S.J. (1994). Sex, gender identity, gender role attitudes, and consumer behavior. Psychology \& Marketing, 11(2). doi:10.1002/ mar.4220110206.

Grum, B., \& Salaj, A.T. (2010). Expectations of potential acquisitions of residential real estate rights in the republic of Slovenia, according to gender, age, education and employment. Geodetski Vestnik, 54(3). doi:10.15292/ geodetski-vestnik.2010.03.501-516.

GUS. (2016). Kobiety i mężczyźni na rynku pracy. Retrieved 12.12.2016 from https://stat.gov.pl.

Kummerow, M., \& Chan Lun, J. (2005). Information and communication technology in the real estate industry: productivity, industry structure and market efficiency. Telecommunications Policy, 29(2-3). doi:10.1016/j. telpol.2004.12.003.

Meffert, H. (1986). Marketing. Grundlagen der absatzpolitik. Wiesbaden: Gabler.

Perju-Mitran, A., \& Budacia, A.E. (2015). Gender differences in modeling the influence of online marketing communication on behavioral intentions. Procedia Economics and Finance, 27, doi:10.1016/S2212-5671(15)01034-5.

Ren, S.W. (2015). Innovation and reform of enterprises in the era of Internet: based on the research of real estate industry. In Proceedings of the 2015 International Conference on Management Science and Innovative Education (MSIE 2015), China.

Seagraves, P., \& Gallimore, P. (2012). The gender gap in real estate sales: negotiation skill or agent selection? Real Estate Economics, 41(3). doi:10.1111/ reec.12006. 
Shu-Man, Y., Ming-Hsun, T., Chun-Chang, L., \& Ming-Tsann, C. (2012). An examination of service quality in a real estate advertising sales agents-formal control mechanism as a moderator. Journal of Information and Optimization Sciences, 33(2-3). doi:10.1080/02522667.2012.10700149.

Staffansson Pauli, K. (2014). Gender structures in the real estate industry. Stockholm: KTH Royal Institute of Technology.

Turek, B. (2012). Jak kobiety kupują mieszkania. Retrieved 9.12.2017 from https://homebroker.pl.

Turek, B. (2013). Kobiety wyprowadzają się o rok wcześniej niż mężczyźni. Retrieved 12.12.2016 from http://biznes.interia.pl.

Zatwarnicka-Madura, B. (2004). Techniki sprzedaży osobistej. Warszawa: CeDeWu.

\section{Acknowledgements}

Author contributions: author has given an approval to the final version of the article.

Funding: this research was fully funded by the Rzeszow University of Technology, Faculty of Management, Department of Marketing statutory sources.

Note: the results of this study were presented at 9th International Conference on Applied Economics Contemporary Issues in Economy (June 22-23, Torun, Poland). 


\section{Appendix}

Table. 1.

The content of analyzed web pages (quantitatively and in \%)

\begin{tabular}{|c|c|c|}
\hline Elements of websites & No. of websites & Share \\
\hline \multicolumn{3}{|l|}{ company presentation: } \\
\hline company as an organization: mission, goals, successes & 24 & 80 \\
\hline company as a team: presentation of the board and employees & 6 & 20 \\
\hline $\begin{array}{l}\text { company as a business partner: standards and principles of cooperation, benefits for } \\
\text { the customer }\end{array}$ & 28 & 93 \\
\hline $\begin{array}{l}\text { company as an advisor: information about services other than sales (credit } \\
\text { counseling etc.) }\end{array}$ & 22 & 73 \\
\hline \multicolumn{3}{|l|}{ information that makes a company trustworthy: } \\
\hline awards, successes, affiliation, social and charitable activities, etc. & 6 & 20 \\
\hline recommendations of satisfied customers & 6 & 20 \\
\hline recommendations of famous people/companies & 5 & 17 \\
\hline partners: consulting companies, organizations and associations, media, etc. & 15 & 50 \\
\hline company in the media (press articles, radio speech and TV) & 4 & 13 \\
\hline $\begin{array}{l}\text { sellers/buyers section (basic information for each of these groups — why should they } \\
\text { entrust the transaction to this company?) }\end{array}$ & 15 & 50 \\
\hline up-to-date offers database & 28 & 93 \\
\hline offers search engine & 22 & 73 \\
\hline registration forms (real estate to buy and sell, customers' and journalist's) applications) & 15 & 50 \\
\hline social media & 8 & 27 \\
\hline \multicolumn{3}{|l|}{ service added value: } \\
\hline guide texts & 16 & 53 \\
\hline data about market (statistics, summaries, etc.) & 8 & 27 \\
\hline credit calculator & 14 & 47 \\
\hline useful links & 15 & 50 \\
\hline information search engine about the real estate market, etc. & 4 & 13 \\
\hline the use of audiovisual technologies & 6 & 20 \\
\hline contact & 30 & 100 \\
\hline
\end{tabular}

Source: Own preparation. 